\title{
PENGARUH KEMAMPUAN KERJA, PERSEPSI PERAN DAN MOTIVASI KERJA TERHADAP KINERJA PEGAWAI ADMINISTRASI UNIVERSITAS NEGERI JAKARTA
}

\author{
BETTY ZELDA SIAHAAN•
}

\begin{abstract}
The objective of this research is to find out the effects of the work ability, perceptions on role, and work motivation of the employees performance at the State University of Jakarta, conducted in 2009. The method used was a correlation study by survey. The sample size was 60 employees, selected at random. The data were analyzed by path analysis after placed in correlation matrix. The results showed as the followings, (1) the work ability and the role the perception have direct effects on work motivation; (2) the work ability and the role perception have direct effects on the employees performance; (3) the work motivation has also a direct effect on performance; (4) the work ability and role the perception have indirect effects on performance through work motivation. The implication of these results is that in the effort to improve the employee performance, the work ability, role perception and the work motivation should be considered.
\end{abstract}

Keywords: work ability, perceptions on role, work motivation, performance.

\section{PENDAHULUAN}

Seiring dengan perkembangan global dan situasi persaingan usaha yang sangat ketat, para pelaku organisasi dituntut melakukan perubahan sehingga dapat menyesuaikan diri terhadap perkembangan lingkungan. Perusaahaan yang dapat bertahan dalam situasi demikian adalah perusahaan yang mampu berkompetisi dalam bidang usaha yang digelutinya. Hal ini berlaku juga pada lembaga pendidikan tinggi. Universitas Negeri Jakarta sebagai lembaga pendidikan tinggi perlu memiliki kemampuan untuk memenuhi kebutuhan pasar, yakni mampu menghasilkan sumberdaya manusia siap terjun kerja di lapangan.

Untuk mencapai hal tersebut harus ditinjau dari dua sisi yakni fungsi edukatif dan fungsi administratif. Selama ini banyak perguruan tinggi lebih menekankan pada fungsi edukatif, yakni pengembangan ilmu pengetahuan semata-mata dan kurang memperhatikan kualitas pelayanan diantaranya kemampuan kerja pegawai administrasi. Fungsi pelayanan terhadap pelanggan yakni aspek kepuasan pelanggan atas jasa, seperti yang diberikan kepada mahasiswa mutlak perlu diperhatikan.

Keberhasilan sebuah organisasi perguruan tinggi sangat ditentukan oleh kepuasan para pelanggannya (dalam hal ini mahasiswa). Produk serta jasa yang diberikan oleh Universitas kepada mahasiswa dan stakeholder lainnya merupakan cermin dari kinerja sumber daya manusia yang ada pada perguruan tinggi tersebut.

Pegawai sebagai salah satu pelaksana langsung dalam proses kegiatan lembaga, perlu mempunyai persepsi peran yang baik dan kemampuan kerja tinggi, sehingga dapat membangkitkan motivasi kerja dan sekaligus akan meningkatkan kinerja pegawai.

\footnotetext{
- Dosen pada Jurusan Fisika FMIPA Universitas Negeri Jakarta
} 
Motivasi kerja sangat berhubungan dengan kinerja, jika motivasi kerja lemah maka kinerja juga akan menurun, mereka akan cepat bosan dalam menghadapi tugas, kurang inisiatif dan juga kurang kreatif; yang mana hal ini merupakan pencerminan rasa ketidakpuasan pegawai terhadap lembaga. Persepsi peran yang kurang baik maupun kemampuan kerja yang rendah, akan melemahkan motivasi kerja pegawai ; hal ini akan berdampak kepada rendahnya kinerja.

Faktor-faktor yang dapat meningkatkan kinerja seorang karyawan dalam suatu organisasi antara lain: kemampuan membawa citra diri, persepsi peran, budaya organisasi, komunikasi interpersonal, promosi jabatan, kompensasi tiap bulan, pengetahuan, pelatihan, motivasi kerja, kemampuan kerja, sikap, minat, perhatian pimpinan, tanggung jawab, kesempatan memperoleh pendidikan yang lebih tinggi, lingkungan kerja, kepuasan kerja dan lain sebagainya.

Namun yang menjadi sasaran utama dalam penelitian ini adalah persepsi peran, kemampuan kerja, dan motivasi kerja. Besarnya pengaruh persepsi peran, kemampuan kerja dan motivasi kerja terhadap kinerja sangat menarik untuk dikaji dalam suatu penelitian. Agar menghasilkan kinerja sesuai denga harapan, maka faktor-faktor di atas tentunya harus dapat berperan dengan baik. Hal inilah yang mendorong penulis perlu mengadakan penelitian tentang faktor-faktor yang mungkin ada kaitannya dengan kinerja pegawai administrasi, diantaranya adalah persepsi peran, kemampuan kerja dan motivasi kerja. Dengan terpenuhinya ketiga faktor tersebut diharapkan akan membawa dampak positip terhadap kelancaran tugas dalam bidang administrasi yang pada akhirnya akan meningkatkan kinerja pegawai administrasi.

Kinerja Pegawai. Menurut Stephen P.Robbins (1998:258) maksud dari evaluasi kinerja dalam organisasi:

1) Memberikan masukan untuk keputusan penting seperti promosi, transfer, dan pemutusan hubungan kerja.

2) Mengidentifikasi kebutuhan pelatihan dan pengembangan.

3) Sebagai suatu kriterium program seleksi.

4) Menunjuk dengan tepat keterampilan dan kompetensi karyawan.

Mosley (2005:195) memaparkan faktor-faktor yang mempengaruhi kinerja seperti gambar di bawah ini:

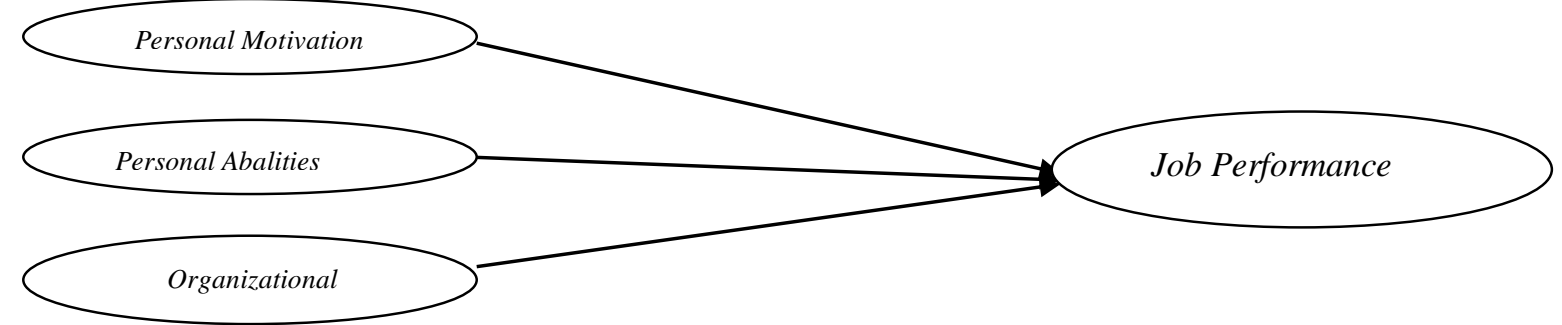

Gambar1 . Faktor-faktor yang memepengaruhi kinerja

Stephen P. Robbins (2001:372) mengatakan bahwa kinerja merupakan fungsi perkalian dari kemampuan, kepemimpinan dan kesempatan untuk berpartisipasi, yaitu: Kinerja $=\mathrm{f}($ Kemampuan $\mathrm{x}$ Kepemimpinan $\mathrm{x}$ kesempatan untuk berprestasi.

Menurut Collquitt (2009:37) kinerja biasanya didefenisikan sebagai nilai dari sekumpulan tingkah laku pekerja yang bisa berdampak positip atau negatip terhadap keberhasilan atau pencapaian dari tujuan suatu organisasi. 
Menurut James A. F. Stoner (2003:165) kinerja adalah fungsi dari kepemimpinan, kemampuan dan pemahaman peran seseorang atas tugas dan perilaku yang diperlukan untuk mencapai kinerja yang tinggi.

Colquitt (2009:38) mengatakan secara umum kinerja dapat digolongkan dalam tiga kategori, yaitu: kinerja tugas, perilaku kewargaan, dan perilaku kontra-produktif. Berdasarkan uraian di atas, kinerja memiliki tiga dimensi: kinerja tugas (Task Performance), perilaku kewargaan (Citizenship Behavior, dan perilaku kontraproduktif (Counter Productive Behavior). Untuk mempersempit dan mempertajam fokus pembahasan, maka penelitian ini membahas dua dimensi kinerja yaitu: kinerja tugas dan perilaku kewargaan.

Sehingga dapat disimpulkan yang dimaksud dengan kinerja adalah nilai-nilai dari seperangkat perilaku karyawan yang memberi kontribusi positip terhadap pencapaian tujuan organisasi; yang diidentifikasikan sebagai Task Performance dan Citizenship Behavior.

Kemampuan Kerja. Menurut Gibson (2006:96) kemampuan merupakan suatu karakter yang dimiliki seseorang atau yang diperoleh melalui belajar, yang menyebabkan seseorang dapat melakukan sesuatu secara mental atau fisik. Kemampuan berkenaan dengan kapasitas setiap orang untuk melakuakan beberapa tugas dalam suatu pekerjaan. Kemampuan juga adalah penilaian terhadap pekerjaan yang dilakukan.

Colquitt (2009:337) menyatakan bahwa kemampuan adalah fungsi dari genetika dan lingkungan. Keseluruhan kemampuan dari seseorang secara umum dapat digolongkan kedalam tiga kategori yaitu: kemampuan kognitif, kemampuan emosional, dan kemampuan fisik. Secara bersamaan ketiga kemampuan ini menggambarkan apa yang bisa dilakukan seseorang. Dari ketiga jenis kemampuan di atas, yang lebih dominan mempengaruhi kinerja pegawai administrasi perkantoran adalah kemampuan kognitif.

Kinerja dari setiap karyawan akan meningkat jika ditempatkan pada pekerjaan yang cocok/ sesuai dengan kemampuan yang dimiliki oleh karyawan tersebut.

Colquitt (2009:337) menyatakan bahwa kemampuan adalah fungsi dari genetika dan lingkungan. Keseluruhan kemampuan dari seseorang secara umum dapat digolongkan kedalam tiga kategori yaitu: kemampuan kognitif, kemampuan emosional, dan kemampuan fisik. Secara bersamaan ketiga kemampuan ini menggambarkan apa yang bisa dilakukan seseorang. Dari ketiga jenis kemampuan di atas, yang lebih dominan mempengaruhi kinerja pegawai administrasi perkantoran adalah kemampuan kognitif.

Kemampuan kognitif adalah kemampuan yang berhubungan dengan penggabungan dan aplikasi dari pengetahuan dalam pemecahan masalah. Jennifer (2005:53) mengatakan kemampuan kognitif diidentifikasikan kedalam delapan tipe ; kemampuan: verbal, kelancaran kata, berhitung, ruang, mengingat, kecepatan daya tangkap, melihat hubungan, dan deduktif.

Kinerja dari setiap karyawan akan meningkat jika ditempatkan pada pekerjaan yang cocok/ sesuai dengan kemampuan yang dimiliki oleh karyawan tersebut.

Sedangkan kemampuan khusus yang perlu dimiliki oleh pegawai adminstrasi adalah bagaimana pekerjaan administrasi dapat disederhanakan, bagaimana meningkatkan hasil pekerjaan, bagaimana mengembangkan sistem manajemen kearsipan, bagaimana mendesain form, bagaimana memproses data yang ada menjadi informasi yang dapat digunakan oleh organisasi 
Menurut Burton dkk. (2000:25) ada beberapa hal yang harus di miliki agar dapat menjadi pegawai administrasi yang profesional:

1) Mengetahui penggunaan software yang dibutuhkan di kantor.

2) Mengetahui prosedur dalam menyiapkan dan memproses komunikasi tertulismembuat surat, memproses surat ma suk dan keluar serta menyiapkan laporan.

3) Memahami konsep dari prosedur mengirim dan menerima e-mail, online database, dan mengerti penggunaan multimedia.

4) Memahami jasa layanan yang berhubungan dengan prosedur kantor.

5) Mengetahui prosedur dan langkah kerja untuk bernegosiasi dengan pelanggan maupun pegawai.

6) Menggunakan otomatisasi kantor - fotokopi, scanner, facsimile.

7) Menggunakan sumber data yang kredibel, database maupun internet guna mencari informasi.

8) Memahami filing dan records control - prosedur-prosedur filing, aturan, sistem, peralatan, hambatan, penyimpanan.

Berdasarkan uraian di atas dapat disimpulkan, bahwa kemampuan kerja dalam hal ini adalah sebagai kemampuan yang berhubungan dengan penggabungan dan aplikasi pengetahuan dalam pemecahan masalah; yang berhubungan dengan: penggunaaan komputer dan multimedia, pelayanan, pengelolaan administrasi dokumen, pengarsipan dokumen, dan komunikasi.

Persepsi Peran (Role Perceptions). Menurut Duncan (1981 :138), yang dikutip oleh Miftah Thoha, persepsi itu dapat dirumuskan dalam pelbagai cara, tetapi dalam ilmu perilaku khususnya psikologi, istilah ini dipergunakan untuk mengartikan perbuatan yang lebih dari sekedar mendengarkan, melihat, atau merasakan sesuatu.

Menurut Stephen P.Robbins (1996:258) persepsi dapat didefenisikan sebagai suatu proses dengan mana individu-individu mengorganisasikan dan menafsirkan kesan-kesan indera mereka agar memberikan makna bagi lingkungan mereka.

Persepsi dapat didefenisikan sebagai proses menerima, menyeleksi, mengorganisasikan, mengartikan, menguji, dan memberikan reaksi kepada rangsangan pancaindera atau data.

Peran atau dalam bahasa Inggris disebut dengan role, didefenisikan oleh James L.Gibson (2006:255) sebagai "Organized set of behavior expected of an individual in a specific position". Defenisi ini menyatakan bahwa peran adalah suatu set perilaku yang diharapkan dari setiap individu terorganisasi pada posisi tertentu.

Menurut Keith Davis (2002:84) yang dimaksud dengan peran (role) adalah pola tindakan yang diharapkan dari seseorang dalam tindakan yang melibatkan orang lain. Peran mencerminkan posisi seseorang dalam sistem social dengan hak dan kewajiban, kekuasaan dan tanggung jawab yang menyertainya.

Setiap orang tentu memiliki peran yang berbeda dalam situasi yang berbeda; misalnya peran karyawan dalam pekerjaan, peran orang tua dalam keluarga, peran sosial bagi ketua perkumpulan, dan masih banyak lagi peran lainnya. Masing-masing peran menghendaki perilaku yang berbeda-beda.

Menurut R.Wayne Pace and Don F.Faules (2002:140) persepsi peran (role perception) dapat juga diartikan sebagai persepsi kerja adalah menggambarkan persepsi yang dimilki pegawai mengenai aspek-aspek pekerjaan mereka.

Menurut Kreitner (1995:252) persepsi peran (role perceptions) adalah merupakan pandangan seseorang bagaimana seharusnya bersikap atau bertindak dalam situasi 
tertentu. Berdasarkan pada sebuah interpretasi dalam hal meyakini bagaimana seharusnya bersikap, seseorang terikat dalam beberapa jenis tipe dari kelakuan. Keith Davis (2002:85) mengatakan aktivitas para manajer dan karyawan diarahkan oleh persepsi peran (role perceptions) mereka, yaitu apa yang harus dilakukan menurut pandangan mereka dalam peran mereka sendiri, dan bagaimana seyogianya orang lain bertindak dalam peran mereka.

Dari penjelasan di atas yang dimaksud dengan persepsi peran (role perceptions) adalah gambaran seseorang akan hak dan kekuasaan yang dimiliki, serta kewajiban dan tanggung jawab yang juga harus dilakukan atas peran/ tugas yang diemban, dengan indikator: sasaran kerja, jadwal pekerjaan, metoda kerja, dan urutan pekerjaan.

Motivasi Kerja. Motivasi adalah suatu kondisi yang mendorong atau menjadi sebab seseorang melakukan suatu perbuatan atau kegiatan, yang berlangsung secara sadar. Meskipun tidak tertutup kemungkinan bahwa dalam keadaan terpaksa seseorang mungkin saja melakukan suatu kegiatan yang tidak disukainya, sehingga kegiatan yang didorong oleh sesuatu yang tidak disukai berupa kegiatan yang terpaksa dilakukan cenderung berlangsung tidak efektif dan tidak efesien. Menurut Stephen P. Robbins (1997:155) motivasi dapat dirumuskan melalui berbagai defenisi, misalnya: "proses yang menggambarkan intensitas, arah dan ketekunan dari upaya individual dalam mencapai tujuan". Andrew J.DuBrin (2002:88) mengatakan motivasi dalam lingkungan pekerjaan adalah proses dimana tingkah laku dipengaruhi dan diikuti akan keperluan pencapaian tujuan organisasi.

Menurut David McClelland(1995:148), bahwa mereka yang memiliki kebutuhan berprestasi lebih mengejar prestasi pribadi daripada imbalan terhadap hasil pekerjaan, lebih menyukai pekerjaan-pekerjaan di mana mereka memiliki tanggug jawab pribadi, bekerja pada tugas-tugas yang sulit, bergairah melakukan sesuatu lebih baik dan lebih efisien dan tidak suka berhasil secara kebetulan.

Maslow mengemukakan bahwa studi motivasi sebagian merupakan studi tentang tujuan, keinginan dan kebutuhan manusia. Adapun motivasi merupakan hal lain yang sifatnya lebih kompleks dan luas. Istilah motivasi berasal dari kata Latin "Movere" yang berarti menggerakkan.

Menurut Jennifer M.George dan Gareth R.Jones (2005:175), motivasi kerja dapat didefenisikan sebagai kekuatan psikologis dalam diri seseorang yang menentukan arah tingkah laku seseorang di dalam sebuah organisasi, upaya dan ketekunan dalam menghadapi rintangan.

Dari uraian di atas dapat disimpulkan yang dimaksud dengan motivasi kereja adalah kondisi yang mendorong seseorang untuk melakukan serangkaian tindakan yang mengarah kepada tercapainya tujuan tertentu; dengan indikator: arah tingkah laku (direction of behavior), upaya (level of effort), dan ketekunan (level of persistence).

\section{METODE}

Penelitian ini bertujuan untuk untuk mengetahui gambaran pengaruh variabel satu dengan lainnya sebagai berikut:

1. Pengaruh langsung kemampuan kerja terhadap motivasi kerja pegawai administrasi.

2. Pengaruh langsung persepsi peran terhadap motivasi kerja pegawai administrasi.

3. Pengaruh langsung kemampuan kerja terhadap kinerja pegawai administrasi.

4. Pengaruh langsung persepsi peran terhadap kinerja pegawai administrasi. 
5. Pengaruh langsung motivasi kerja terhadap kinerja pegawai administrasi.

6. Pengaruh tidak langsung kemampuan kerja melalui motivasi kerja terhadap kinerja pegawai administrasi.

7. Pengaruh tidak langsung persepsi peran melalui motivasi kerja terhadap kinerja pegawai administrasi.

Penelitian ini dilakukan di Universitas Negeri Jakarta selama 9 (sembilan) bulan, yaitu mulai April 2008 sampai dengan Desember 2009.

Metode yang digunakan dalam penelitian ini adalah metoda survei dengan teknik analisis jalur (path analysis).

Populasi target dalam penelitian ini adalah pegawai administrasi Universitas Negeri Jakarta. Sampel dalam penelitian ini berjumlah 60 orang diambil dengan menggunakan teknik Simple Random Sampling, yaitu cara penarikan sampel yang dilakukan secara acak. Pengumpulan data untuk setiap variabel menggunakan instrumen. Penyusunan instrumen didasarkan pada indikator-indikator untuk setiap variabel dan teori-teori yang telah dibangun, selanjutnya setiap indikator dijabarkan kedalam butir-butir pernyataan.

\section{HASIL PENELITIAN}

\section{Pembahasan Hasil Penelitian}

Berdasarkan hasil pengujian model kausalitas antar variabel, ditemukan bahwa secara umum terdapat pengaruh variabel eksogenus terhadap variabel endogenus. Dalam penelitian ini yang menjadi variabel eksogenus adalah kemampuan kerja, persepsi peran dan motivasi kerja. Sedangkan variabel endogenus adalah kinerja pegawai administrasi.

Hasil penelitian ini menunjukkan baik kemampuan kerja, persepsi peran dan motivasi kerja secara siknifikan berpengaruh langsung positif terhadap kinerja pegawai administrasi. Dengan kata lain, ketiga variabel tersebut dapat digunakan untuk meningkatkan kinerja pegawai administrasi. Untuk jelasnya hasil temuan tersebut diuraikan sebagai berikut:

Dari hasil pengujian model analisis jalur, ternyata kemampuan kerja berpengaruh langsung positif terhadap motivasi kerja. Temuan ini sesuai dengan teoriteori yang telah diuraikan pada bab II, bahwa kemampuan kerja pegawai dalam hal ini kemampuan kognitif sangat berperan mendorong pegawai untuk bertindak mencapai tujuan organisasi.

Dalam penelitian ini digunakan lima indikator untuk mengukur kemampuan kerja pegawai, yakni: penggunaan komputer dan multimedia, pelayanan, pengelolaan administrasi dokumen, pengarsipan dokumen, dan ketrampilan berkomunikasi. Untuk meningkatkan kemampuan kerja pegawai dapat dilakukan melalui pelatihan dan kursus-kursus secara berkala maupupun melalui jalur pendidikan untuk kelima indikator di atas, sesuai dengan perkembangan ilmu dan teknologi.

Sehingga, dengan meningkatkan kemampuan menggunaan komputer dan multimedia, pengelolaan administrasi dokumen, pengarsipan dokumen, ketrampilan berkomunikasi, serta kemampuan melayani dengan baik; akan meningkatkan kemampuan kerja yang sekaligus meningkatkan motivasi kerja pegawai. 
Hasil penelitian ini juga membuktikan bahwa persepsi peran berpengaruh langsung positif terhadap motivasi kerja. Dengan kata lain pegawai yang mempunyai persepsi peran yang baik, mereka lebih termotivasi untuk bekerja lebih baik.

Temuan tersebut sejalan dengan pendapat Mc.Shane yang mengatakan karyawan dengan persepsi peran yang jelas merasa lebih terlibat dalam pekerjaan mereka, karena tahu dimana untuk mengarahkan usaha mereka. Dalam penelitian ini digunakan empat indikator untuk mengukur persepsi peran pegawai, yakni: sasaran kerja, jadwal pekerjaan, metoda kerja, urutan pekerjaan.

Cara yang paling mendasar untuk meningkatkan persepsi peran adalah pegawai menerima tugas disertai dengan uraian pekerjaan yang jelas dan diikuti dengan pembinaan berkelanjutan menyangkut dengan keempat indikator di atas. Apabila peran seseorang tidak dirumuskan secara jelas di dalam rumusan deskripsi tugas kerja, menyebabkan penyandang peran menjadi bingung dalam melakukan tugas kerja, maka timbul kemenduaan peran.

Akhirnya dapat dikatakan bahwa untuk meningkatkan persepsi peran pegawai, dalam memberikan tugas kepada pegawai harus disertai dengan uraian pekerjaan yang jelas, disertai dengan pembinaan yang berkelanjutan; sekaligus akan dapat meningkatkan motivasi kerja pegawai.

Berdasarkan hasil analisis jalur, ternyata motivasi kerja berpengaruh langsung positif terhadap kinerja. Dengan kata lain pegawai yang mempunyai motivasi kerja yang kuat dapat meningkatkan kinerja pegawai tersebut. Temuan ini sesuai dengan teori-teori yang telah diuraikan pada bab II, diantaranya pendapat McClelland bahwa mereka yang memiliki kebutuhan berprestasi lebih mengejar prestasi pribadi daripada imbalan terhadap hasil pekerjaan, lebih menyukai pekerjaan-pekerjaan dimana mereka memiliki tanggug jawab pribadi, bekerja pada tugas-tugas yang sulit, bergairah melakukan sesuatu lebih baik dan lebih efisien dan tidak suka berhasil secara kebetulan. Dalam penelitian ini digunakan tiga indikator untuk mengukur motivasi kerja pegawai, yakni: arah tingkah laku, upaya, dan ketekunan.

Gambaran tentang pengaruh motivasi kerja terhadap kinerja pegawai Universitas Negeri Jakarta dapat dilihat antara lain dari melaksanakan tugas: berusaha memperoleh hasil yang sempurna, tepat waktu, tanpa pamrih, sesuai dengan uraian kerja, pantang surut sampai mencapai hasil maksimal, berupaya mengikuti penataran, dan terdorong mengerjakan pekerjan yang menantang.

Ringkasnya dapat dikatakan tingginya skor pada indikator-indikator motivasi kerja, membuktikan pula meningkatnya skor kinerja pegawai tepatnya, tugas rutin dan tugas adaptif, suka menolong, memiliki kebaikan, sikap sportif, bicara vokal dan bersifat kepoloporan.

Hasil penelitian ini juga membuktikan bahwa kemampuan kerja berpengaruh langsung positif terhadap kinerja. Dengan kata lain pegawai yang mempunyai kemampuan kerja yang tinggi, dapat meningkatkan kinerja pegawai tersebut.

Temuan tersebut sejalan dengan pendapat Robbins yang mengatakan kemampuan karyawana juga membuat perbedaan sikap dan perilaku dalam kinerja tugas. Pendapat Colquitt juga menunjang hasil penelitian ini, yang mengatakan dari ketiga jenis penggolongan kemampuan (kemampuan kognitif, kemampuan emosional dan kemampuan fisik), yang lebih dominan mempengaruhi kinerja pegawai administrasi adalah kemampuan kognitif. 
Fakta di atas tercakup kedalam lima indikator dalam penelitian ini yang digunakan untuk mengukur kemampuan kerja, yaitu penggunaan komputer dan multimedia, pelayanan, pengelolaan administrasi dokumen, pengarsipan dokumen, dan ketrampilan berkomunikasi.

Akhirnya dapat dikatakan tingginya skor pada indikator-indikator kemampuan kerja, membuktikan pula dapat meningkatkan skor kinerja pegawai tepatnya, tugas rutin dan tugas adaptif, suka menolong, memiliki kebaikan, sikap sportif, bicara vokal dan bersifat kepoloporan.

Berdasarkan model analisis jalur, ternyata persepsi peran berpengaruh langsung positif terhadap motivasi kerja. Temuan ini sesuai dengan teori-teori yang telah diuraikan pada bab II, bahwa persepsi peran pegawai sangat berperan mendorong pegawai untuk bertindak mencapai tujuan organisasi.

Dalam penelitian ini digunakan empat indikator untuk mengukur persepsi peran pegawai, yakni: Dalam penelitian ini digunakan empat indikator untuk mengukur persepsi peran pegawai, yakni: sasaran kerja, jadwal pekerjaan, metoda kerja, urutan pekerjaan.

Untuk meningkatkan persepasi peran pegawai dapat dilakukan melalui pemberian tugas kepada pegawai disertai dengan uraian pekerjaan yang jelas dan diikuti dengan pembinaan berkelanjutan. Ringkasnya, dengan meningkatkan persepsi peran, pegawai bekerja mengacu kepada sasaran kerja, mematuhi jadwal, mampu menggunakan metoda kerja, dan bekerja secara berurutan yang sekaligus meningkatkan kinerja pegawai.

Pengaruh langsung positif kemampuan kerja terhadap motivasi kerja dan terhadap kinerja telah diuraikan pada bagian terdahulu, pada bagian ini akan dibahas tentang hasil temuan yang menyatakan adanya pengaruh tidak langsung positip kemampuan kerja, dan persepsi peran melalui motivasi kerja terhadap kinerja pegawai administrasi.

Berdasarkan analisis jalur yang dijadikan sebagai acuan dari analisis penelitian ini diketahui terdapat dua (2) pengaruh tidak langsung positif yaitu:

1) Dengan terbukti positifnya pengaruh langsung Kemampuan Kerja dan Motivasi Kerja terhadap Kinerja, terbukti positif pula pengaruh tidak langsung, Kemampuan Kerja terhadap Kinerja Pegawai administrasi melalui Motivasi kerja.

2) Demikian pula positif pengaruh langsung: Persepsi Peran dan Motivasi Kerja terhadap Kinerja. Maka dengan sendirinya terbukti pula positif adanya pengaruh tidak langsung Persepsi Peran terhadap Kinerja melalui Motivasi Kerja.

\section{PENUTUP}

Kesimpulan: Berdasarkan hasil analisis data dan perhitungan statistik seperti yang diuraikan pada bab sebelumnya, maka penelitian ini menghasilkan temuan dan kesimpulan sebagai berikut:

1. Kinerja pegawai dipengaruhi baik secara langsung positif maupun tidak langsung positif oleh berbagai variabel diantaranya: kemampuan kerja, persepsi peran, dan motivasi kerja.

2. Faktor kemampuan kerja memberikan pengaruh positif baik langsung maupun tidak langsung; karena para pegawai administrasi telah mampu menggunakan komputer serta multi media dengan baik, memberikan pelayanan, dapat mengelola 
administrasi dokumen, dapat mengarsipkan dokumen dengan baik, dan berkomunikasi dengan baik.

3. Faktor persepsi peran memberikan pengaruh positif, baik langsung maupun tidak langsung karena pegawai administrasi bekerja mengacu kepada sasaran kerja, mematuhi jadwal, mampu menggunakan metoda kerja, dan bekerja secara berurutan.

4. Faktor motivasi kerja memberikan pengaruh langsung positif, karena mampu menggerakkan pagawai administrasi dengan arah tingkah laku maupun tanggung jawab kerja, selalu berupaya menghasilkan kerja yang baik, tekun melakukan pekerjaan, dan berusaha mengembangkan diri.

\section{Implikasi:}

Berdasarkan refleksi hasil temuan penelitian, terbukti bahwa kemampuan kerja, persepsi peran dan motivasi kerja berpengaruh terhadap kinerja pegawai administrasi Universitas Negeri Jakarta. Untuk itu perlu dilakukan peningkatan kemampuan kerja, perbaikan persepsi peran dan penguatan motivasi kerja untuk memperoleh kinerja terbaik agar tercapai tujuan organisasi.

Implikasi penelitian ini dapat dikemukakan sebagai berikut:

1. Upaya meningkatkan kinerja pegawai administrasi Universitas Negeri Jakarta dengan peningkatan kemampuan kerja.

Hasil penelitian ini membuktikann bahwa, terdapat pengaruh langsung positif

Berdasarkan kesimpulan penelitian, dapat dipaparkan implikasi dari hasil penelitian sebagai berikut:

1. Untuk meningkatkan kinerja pegawai administrasi dilakukan dengan peningkatan kemampuan kerja, memperbaiki persepsi peran dan menguatkan motivasi kerja.

2. Kemampuan kerja pegawai administrasi terbentuk berorientasi pada penggunaan komputer serta multi media, memberikan pelayanan, mengelola administrasi dokumen, pengarsipan dokumen, dan kemampuan berkomunikasi.

2. Kemampuan kerja ini sangat kuat dan kondusif untuk mendukung upaya peningkatan kinerja pegawai administrasi.

3. Untuk meningkatkan kinerja dibutuhkan persepsi peran yang baik, yakni bekerja mengacu kepada sasaran kerja, mematuhi jadwal, menggunakan metoda kerja, dan bekerja secara berurutan.

4. Motivasi kerja yang kuat dapat meningkatkan kinerja. Motivasi kerja pegawai administrasi yang kuat terbentuk berorientasi pada arah tingkah laku maupun tanggung jawab kerja, upaya untuk hasil kerja yang baik, ketekunan dalam melakukan pekerjaan, dan usaha pengembangan diri

\section{Saran:}

Dari kesimpulan dan implikasi yang sudah dikemukakan, maka dapat dikemukakan beberapa saran untuk mewujudkan peningkatan kinerja pegawai administrasi sebagai salah satu komponen yang terlibat dalam proses kegiatan lembaga pendidikan, diantaranya:

1. Kinerja pegawai administrasi dapat ditingkatkan secara signifikan, mengingat lembaga UNJ berperan strategik dengan berupaya:

a. Melakukan penilaian kinerja terhadap pegawai administrasi secara periodik, dan ditindaklanjuti. 
b. Agar menempatkan pegawai pada tempat yang sesuai dengan bidang kemampuannya.

2. Dalam meningkatkan kemampuan kerja pagawai hendaknya lembaga:

a. Membekali pegawai agar mengetahui dan memahami berbagai macam pendekatan-pendekatan starategi yang tepat untuk dapat meningkatkan pengetahuan praktis guna meningkatkan kemampuan kerja .

b. Memberi kesempatan kepada pegawai administrasi untuk mengikuti pelatihanpelatihan secara periodik, terutama mengikuti perkembangan teknologi.

3. Pegawai administrasi hendaknya:

a. Memahami dengan baik bahwa hak dan kekuasaan yang dimiliki, serta kewajiban dan tanggung jawab yang diemban harus dilakukan secara bersama-sama atas peran/ pekerjaannya.

b. Mempunyai kesadaran akan perlunya mempelajari dan melatih berbagai ketrampilan yang mempunyai kontribusi dalam hal meningkatkan kemampuan kerjanya, baik melalui pendidikan dan pelatihan formal maupun non formal.

4. Bagi pihak pengambil kebijakan, kiranya:

a. Memberi kesempatan kepada pegawai administrasi untuk mengikuti pendidikan pada jenjang yang lebih tinggi, sehingga pegawai memiliki kesempatan untuk memperbaiki nasibnya, sekaligus hal ini akan menguatkan motivasi kerja pegawai.

b. Agar memberikan insentif bulanan tambahan kepada pegawai yang mempunyai kinerja yang tinggi, secara periodik setiap tahun pada setiap departemen.

Dengan melakukan upaya-upaya tersebut di atas, maka Kinerja Pegawai Administrasi Universitas Negeri Jakarta akan meningkat sesuai dengan yang diharapkan.

\section{DAFTAR RUJUKAN}

Colquitt Jason A, LePine Jeffery A and Wesson Michael J, Organizational Behavior Improving Performance and Commitment in The Workplace, International Edition, New York: McGraw-Hill, 2009.

Davis Keith and Newstrom John W., Organizational Behavior, International Edition, New York: McGraw-Hill Irwin, 2002.

DuBrin J. Andrew, Fundamental of Organizational Behavior, South-Western: Thomson Learning, 2002

George M.Jennifer and R.Jones Gareth,Understanding And Managing Organizational Behavior, Fourth Edition, New Jersey: Pearson Prentice Hall, 2005.

Gibson James L., Organizations: Behavior, Structure, Processes, International Edition, New York: McGraw-Hill Companies, 2006.

Kreitner Robert \& Kinicki Angelo, Organizational Behavior, Seventh Edition, New York: McGraw-Hill, 2007. 
Pace R.Wayne and Faules F.Don, Komunikasi Organisasi Strategi Meningkatkan Kinerja Perusahaan alih bahasa Deddy Mulyana, Bandung: PT.Remaja Rosdakarya, 2002.

Robbins Stepphen P, Organizational Behavior, New Jersey: Prentice-Hall, Inc., 2001. 